\title{
Evaluation of Total Fecal Collection for Measuring Cattle Forage Intake
}

\author{
JERRY L. HOLECHEK, HELEN WOFFORD, DAVE ARTHUN, M.L. GALYEAN, AND JOE D. WALLACE
}

\begin{abstract}
Conventional digestibility trials with steers were conducted to evaluate relationships between actual forage intake and estimated forage intake using the total fecal collection procedure. Actual forage intake of 6 of the 9 forages fed was not accurately estimated by the widely used technique of dividing total fecal output by forage indigestibility estimated by in vitro procedures. This was because 48-h in vitro digestibility poorly estimated in vivo digestibility of 6 forages. Regression equations based on in vivo-in vitro digestibility relationships can reduce but not solve this problem because in vivo processes such as mastication and rumination are bypassed with in vitro techniques. The use of a 36-h microbial digestion period for nongrasses and a 72-96-h microbial digestion period for grasses shows potential to improve in vitro digestibility estimates of cattle in vivo digestibility. Another potential means of improving in vitro digestibility estimates is to select the highest digestibility value from forage or diet samples subjected to 36-, 48-, 60-, 72-, 84- and 96-h microbial digestion periods.
\end{abstract}

Although mechanisms controlling forage intake in ruminants have been described by Ellis (1978), Mertens (1977), Church (1979), Van Soest (1982), and Mertens and Ely (1982), present techniques to measure intake of pasture and range forages by ruminants are laborious, costly, and subject to numerous errors (Cordova et al. 1978, Kartchner and Campbell 1980). The total fecal collection method discussed by Van Dyne (1969) has become the most favored approach for estimating forage intake by domestic ruminants. Although this procedure has been widely used, evaluation of its accuracy is limited (Van Dyne and Meyer 1964). Our objective was to evaluate the total fecal collection/indigestibility method of Van Dyne (1969) for determining intake.

\section{Methods}

Two independent studies were conducted in 1980 and 1982 at the New Mexico State University farm. Details of each study will be reported separately.

\section{Study 1}

Three feeding trials were conducted between May and September of 1980. Steers were fed alfalfa (Medicago sativa) hay for 3 weeks before each trial. Five Hereford $\times$ Angus yearling steers, weighing approximately $340 \mathrm{~kg}$ each, were used in each trial. Trials were 14 days long with 10 days for adaptation and 4 days for data collection. Schneider and Flatt (1975:124) concluded that a 5-day adjustment period was adequate to clear previously fed diets from the digestive tract; Dubose and Embry (1956) reported that a 4-day collection period was sufficient to quantify fecal excretion in steers and lambs.

Trials were in drylot pens where steers were fed ad libitum individually. Feed intake was determined by conventional handfed methods (Schneider and Flatt 1975:57). Steers were harnessed with fecal collection bags. Total fecal output was measured daily. Forages fed in the $\mathbf{3}$ drylot trials included milo hay (Sorghum vulgare) that had the heads removed, alfalfa hay, and oat hay (Avena sativa) that contained about $10 \%$ alfalfa. Feed was avail-

\footnotetext{
Authors are associate professor, graduate research assistants, associate professor, and professor, Department of Animal and Range Sciences, New Mexico State University, Las Cruces 88003.

Funding for the study was provided by the New Mexico Agr. Exp. Sta. This is journal article 1115 of the Agr. Exp. Sta., New Mexico State University, Las Cruces 88003.

Manuscript accepted 4 June 1985.
}

able free choice throughout the day.

Five esophageal fistulated cows were used to collect diet samples in all 3 trials for diet in in vitro organic matter digestibility, crude protein, and fiber evaluation. In vivo organic matter digestibility of the milo, alfalfa, and oat hays was determined by the conventional procedure (Schneider and Flatt 1975).

\section{Study 2}

Study 2 was conducted with 6 yearling steers, weighing approximately $273 \mathrm{~kg}$, in 6 digestion trials during the summer of 1982 . Six different hays representing 2 forage classes ( 3 grasses and 3 nongrasses) were fed to the 6 steers in a Latin square design. All 6 hays were fed in each 15-day trial and randomized within rows and columns. Hays used were alfalfa, Eski sainfoin (Onobrychis viciaefolia), kochia (Kochia scoparia), millet (Panicum miliaceum), timothy (Phleum pratense), and silver bluestem (Bothriochloa saccharoides) prairie hay. Steers were confined to $6 \times 15 \mathrm{~m}$ individual pens. Hays were chopped to a $2-4 \mathrm{~cm}$ particle size to reduce selective feeding.

Intake was determined by conventional hand-fed methods (Schneider and Flatt 1975:57) and estimated by the procedure of Van Dyne (1969) described in Study 1. Feed was available free choice daily, and intake was evaluated for each steer daily for 5 days after 10 days of adjustment to the feed.

We measured total fecal output in collection bags during the same 5 days we measured intake. During each 5 days of intake and fecal output measurement, samples of the feed offered to each steer were collected for laboratory analyses.

\section{Nutritive Analysis}

Preparation of samples for nutritive analysis and nutritive analysis procedures were the same for both studies. Feed and fecal samples were ground through a $1-\mathrm{mm}$ screen in a Wiley laboratory mill and dry matter and ash content were determined following AOAC (1980). Feed samples (esophageal fistula samples in Study 1) for each steer/feed combination were analyzed for Kjeldahl $\mathbf{N}$, $P$, and ether extract (AOAC 1980) and neutral detergent fiber, acid detergent fiber, and acid detergent lignin using Goering and Van Soest (1970) procedures. Crude protein ( $\mathrm{N} \% \times 6.25)$, hemicellulose, and cellulose were calculated. In vitro digestibility was evaluated following Tilley and Terry (1963) as modified by Moore (1970) and Harris (1970). We composited rumen inoculum from 2 steers fed alfalfa hay. In vitro digestibility (48-h) of all samples was calculated from 3 replicates in each of 3 runs. In Study 2 , microbial digestion periods of $0-, 4-, 8-, 24-, 36-, 60-, 72-, 84-$ and $96-h$ were used as well as the standard $48-h$ period. Two runs of triplicate tubes were used for all digestion periods in Study 2. Chemical composition of the 9 feeds is shown in Table 1.

For each feed we compared actual intake, estimated intake using total fecal output divided by in vivo indigestibility, and estimated intake using total fecal output divided by 48 -h in vitro indigestibility using analysis of variance for a completely randomized design and LSD mean separation (Steel and Torrie 1960). Simple linear correlation was used to evaluate the relationship between in vivo and $48-\mathrm{h}$ in in vitro digestibility.

\section{Results and Discussion}

Actual forage intake and estimated forage intake using the procedure of Van Dyne (1969) differed $(P<.05)$ for 6 of the 9 forages in our study (Table 2). However, intakes estimated from 
Table 1. Forage nutritional characteristics for Studies 1 and 2.

\begin{tabular}{|c|c|c|c|c|c|c|c|c|c|}
\hline \multirow[b]{2}{*}{ Forage characteristics } & \multicolumn{3}{|c|}{ Study 1} & \multicolumn{6}{|c|}{ Study 2} \\
\hline & $\begin{array}{l}\text { Milo } \\
\text { hay }\end{array}$ & $\begin{array}{l}\text { Alfalfa } \\
\text { hay }\end{array}$ & $\begin{array}{l}\text { Oat } \\
\text { hay }\end{array}$ & $\begin{array}{l}\text { Millet } \\
\text { hay }\end{array}$ & $\begin{array}{l}\text { Timothy } \\
\text { hay }\end{array}$ & $\begin{array}{l}\text { Bluestem } \\
\text { hay }\end{array}$ & $\begin{array}{l}\text { Alfalfa } \\
\text { hay }\end{array}$ & $\begin{array}{l}\text { Sainfoin } \\
\text { hay }\end{array}$ & Kochia \\
\hline Crude protein $\%$ & 4.9 & 25.7 & 18.0 & 13.6 & 7.8 & 6.5 & 20.2 & 21.2 & 8.9 \\
\hline Phosphorus $\%$ & - & - & - & .20 & .11 & .10 & .23 & .40 & .18 \\
\hline Ether extract $\%$ & 1.75 & 1.76 & 2.00 & 2.01 & 2.22 & 2.19 & 1.98 & 1.94 & 1.62 \\
\hline Neutral detergent fiber $\%$ & 76.9 & 48.1 & 74.2 & 68.7 & 70.2 & 77.9 & 44.4 & 52.3 & 68.1 \\
\hline Acid detergent fiber $\%$ & 57.5 & 40.5 & 50.0 & 40.8 & 40.5 & 47.5 & 35.2 & 47.0 & 43.4 \\
\hline Acid detergent lignin $\%$ & 8.4 & 9.6 & 11.3 & 3.2 & 5.3 & 6.2 & 7.5 & 9.3 & 6.8 \\
\hline Cellulose $\%$ & 49.1 & 30.9 & 38.7 & 37.6 & 35.1 & 41.2 & 27.6 & 37.7 & 36.6 \\
\hline Hemicellulose $\%$ & 19.4 & 7.6 & 24.2 & 27.9 & 29.7 & 30.4 & 9.2 & 5.3 & 24.7 \\
\hline Cellulose + Hemicellulose \% & 64.5 & 38.5 & 62.9 & 65.6 & 64.8 & 71.6 & 36.8 & 43.0 & 61.3 \\
\hline Digestibility \% (in vivo) & 54.0 & 71.0 & 67.0 & 72.0 & 69.0 & 60.0 & 69.0 & 70.0 & 59.0 \\
\hline Digestibility \% (in vitro) & 56.0 & 61.0 & 48.0 & 68.0 & 60.0 & 47.0 & 65.0 & 69.0 & 52.0 \\
\hline Organic matter intake ( $\%$ body weight) & .87 & 1.98 & 2.00 & 2.55 & 2.23 & 1.21 & 2.74 & 2.32 & 1.18 \\
\hline \multirow{2}{*}{$\begin{array}{l}\text { Digestible organic matter intake } \\
\text { (\% body weight) }\end{array}$} & & & & & & & & & \\
\hline & .47 & 1.41 & 1.34 & 1.84 & 1.54 & .73 & 1.89 & 1.62 & .70 \\
\hline
\end{tabular}

All forage nutritive quality data including in vitro and in vivo digestibility are on an organic matter basis.

Table 2. A comparison of actual forage intake (organic matter, $\%$ body weight) with forage intake estimated from total fecal output combined with in vivo and in vitro organic matter digestibilities.

\begin{tabular}{lllllll}
\hline \hline & \multicolumn{5}{c}{$\begin{array}{c}\text { Estimated }^{\mathrm{a}, \mathrm{b}} \\
\text { intake (in vivo } \\
\text { digestibility) }\end{array}$} & $\begin{array}{c}\text { Estimated } \\
\text { int, } \\
\text { intake (in vitro } \\
\text { digestibility) }\end{array}$ \\
\hline $\begin{array}{l}\text { Study 1 } \\
\text { Milo }\end{array}$ & $0.87^{\mathrm{d}}$ & $(9)$ & $.78^{\mathrm{d}}$ & $(9)$ & $.82^{\mathrm{d}}$ & $(8)$ \\
Alfalfa & $1.98^{\mathrm{d}}$ & $(6)$ & $2.07^{\mathrm{d}}$ & $(6)$ & $1.54^{\mathrm{e}}$ & $(5)$ \\
Oat & $2.00^{\mathrm{d}}$ & $(5)$ & $2.12^{\mathrm{d}}$ & $(5)$ & $1.35^{\mathrm{e}}$ & $(6)$ \\
Study 2 & & & & & & \\
Millet & $2.55^{\mathrm{d}}$ & $(2)$ & $2.61^{\mathrm{d}}$ & $(2)$ & $2.28^{\mathrm{e}}$ & $(3)$ \\
Timothy & $2.23^{\mathrm{d}}$ & $(4)$ & $2.23^{\mathrm{d}}$ & $(4)$ & $1.77^{\mathrm{e}}$ & $(4)$ \\
Bluestem & $1.21^{\mathrm{d}}$ & $(7)$ & $1.10^{\mathrm{d}}$ & $(8)$ & $.83^{\mathrm{e}}$ & $(9)$ \\
Alfalfa & $2.74^{\mathrm{d}}$ & $(1)$ & $2.71^{\mathrm{d}}$ & $(1)$ & $2.40^{\mathrm{e}}$ & $(2)$ \\
Sainfoin & $2.32^{\mathrm{d}}$ & $(3)$ & $2.57^{\mathrm{d}}$ & $(3)$ & $2.48^{\mathrm{d}}$ & $(1)$ \\
Kochia & $1.18^{\mathrm{d}}$ & $(8)$ & $1.24^{\mathrm{d}}$ & $(7)$ & $1.04^{\mathrm{d}}$ & $(7)$ \\
\hline
\end{tabular}

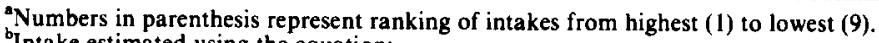
Intake estimated using the equation: Organic matter intake $(\% \mathrm{BW})=$

$(100) \times($ total fecal organic matter output, $\% \mathrm{BW})$

(100) - (\% in vivo organic matter digestibility)

'Intake estimated using the equation:

Organic matter intake $(\% \mathrm{BW})=$

(100) $\times$ (total fecal organic matter output, $\% \mathrm{BW}$ )

(100) - (\% in vivo organic matter digestibility)

${ }^{d, e}$ Means in the row with different superscripts differ $(P<.05)$.

total fecal output and in vivo digestibility were in close agreement with actual intake for all 9 forages (Table 2). We conclude that the procedure of Van Dyne (1969), which uses 48-h in vitro digestibility to estimate in vivo digestibility, may frequently be biased because in vivo and 48-h in vitro digestibilitics may be poorly correlated $(r=.65)$. We consider the regression $S y x=(=3.66)$ excessive for reasonable predictive accuracy of in vivo digestibility. With the exception of milo hay, in vitro digestibility underestimated in vivo digestibility in our study (Table 1). Studies with sheep (Wilkins and Grimes 1966, McLeod and Minson 1974), mule deer (Urness et al. 1977), goats (Sidahmed et al. 1981), and elk (Brooks and Urness 1984) have shown in vitro digestibility values from the Tilley and Terry (1963) technique can differ substantially ( 5 units or more) from in vivo digestibility for many feeds. In contrast, Scales et al. (1974) found in vivo digestibility values of 6 feeds fed to sheep were accurately evaluated by the Tilley and Terry (1963) technique.

A major problem with the Tilley and Terry (1963) procedures is that rumen retention time varies considerably among forages (Campling et al. 1961, Ingalls et al. 1966, Milchunas et al. 1978) and animal species (Poppi et al. 1980, Hendricksen et al. 1981). Ingalls et al. (1966) and Milchunas et al. (1978) indicated grasses have slower passage rates than dicots if their digestibilities are similar. Consequently, the 48-h microbial digestion period required by the Tilley and Terry (1963) technique may be too brief for grasses and too long for legumes. Table 3 shows $0-, 8-, 24-, 36-, 48-, 72-, 84-$ and 96-h microbial digestion periods and in vivo digestibility for the 6

Table 3. In vitro digestibility $\%$ for 9 periods of microbial digestion and in vivo digestibility $\%$ of the 6 forages in Study $2^{a}$.

\begin{tabular}{|c|c|c|c|c|c|c|c|c|c|c|c|c|}
\hline & \multicolumn{12}{|c|}{ Feed \% Digestibility } \\
\hline & \multicolumn{2}{|c|}{ Alfalfa } & \multicolumn{2}{|c|}{ Sainfoin } & \multicolumn{2}{|c|}{ Kochia } & \multicolumn{2}{|c|}{ Millet } & \multicolumn{2}{|c|}{ _ Timothy } & \multicolumn{2}{|c|}{ Bluestem } \\
\hline & $\bar{x}$ & $\mathrm{SE}$ & $\bar{x}$ & SE & $x$ & SE & $\bar{x}$ & $\mathrm{SE}$ & $\bar{x}$ & SE & $\bar{x}$ & $\mathrm{SE}$ \\
\hline \multicolumn{13}{|l|}{$\begin{array}{l}\text { Digestion } \\
\text { Period (h) }\end{array}$} \\
\hline 0 & 40 & .52 & 34 & .06 & 28 & .12 & 28 & 1.58 & 25 & .25 & 19 & .49 \\
\hline 8 & 50 & .50 & 50 & .12 & 34 & .17 & 37 & 1.31 & 28 & .53 & 22 & .18 \\
\hline 24 & 62 & .40 & 63 & .89 & 48 & .49 & 55 & 1.96 & 49 & .34 & 34 & 1.76 \\
\hline 36 & 67 & .41 & 67 & 1.24 & 52 & 2.01 & 67 & 1.44 & 56 & 1.35 & 42 & .65 \\
\hline 48 & 65 & .25 & 69 & .86 & 51 & .59 & 68 & .78 & 60 & 1.00 & 47 & .76 \\
\hline 60 & 65 & .38 & 69 & .26 & 52 & 1.57 & 69 & 1.00 & 63 & 1.21 & 52 & 1.22 \\
\hline 72 & 65 & .47 & 68 & .23 & 53 & .60 & 70 & 1.04 & 64 & 1.37 & 51 & .11 \\
\hline 84 & 65 & .59 & 69 & .61 & 54 & .45 & 70 & .05 & 65 & .77 & 54 & .49 \\
\hline 96 & 66 & .53 & 70 & .09 & 53 & .39 & 71 & .12 & 67 & 1.08 & 56 & 1.23 \\
\hline In vivo digestibility & 69 & .87 & 70 & 3.22 & 59 & 3.46 & 72 & 2.20 & 69 & 2.04 & 60 & 2.94 \\
\hline
\end{tabular}

All data are on an organic matter basis. 
forages in Study 2. We surmise that a $36-\mathrm{h}$ microbial digestion period for dicots and a 72-96-h microbial digestion period for grasses would provide more accurate estimates of cattle in vivo digestibility than the standard 48-h period. An alternative would be to observe 36-, 48-, 60-, 72-, 84-, and 96-h microbial digestions and select the highest in vitro digestibility value to estimate in vivo digestibility. The rationale for this approach is based on our observation that the time period giving the highest in vitro digestibility value for each feed in Study 2 also closely represented the in vivo digestion coefficient (Table 3 ). However, these procedures could inflate digestibility estimates of forages retained in the rumen for periods shorter than required for complete digestion. Because of its low fiber content and high intake (Table 1), the alfalfa in our study probably had a rapid passage rate. Its in vivo digestibility was estimated to within 2 units (Table 3) by both procedures we have suggested. Therefore, we believe these procedures have potential to improve in vitro estimates of in vivo digestibility. Information on mean rumen retention times of various range forages by cattle is needed to further establish the reliability of the procedures we have described.

Urness et al. (1977) and Brooks and Urness (1984) indicate the regression equations between in vivo and in vitro digestibilities can be used to improve the accuracy of in vitro digestibility estimates. However in vivo digestibility of many forages will still be poorly estimated even if regressions are used. The procedures we have described are much simpler than regression techniques and may be equal or superior in accuracy, particularly for forages with long retention times. Our suggestions appear to merit further study.

\section{Literature Cited}

A.0.A.C. 1980. Official methods of analysis (13th ed.). Association of Official Analytical Chemists. Washington, D.C.

Brooks, J., and P.J. Urness. 1984. Comparison of in vivo and in vitro digestibility of forages by elk. J. Anim. Sci. 58:963-971

Campling, R.C., M. Freer, and C.C. Balch. 1961. Factors affecting the voluntary intake of food by cows. 2 . The relationship between intake of roughages, the amount of digesta in the reticulo-rumen and the rate of disappearance of digesta from the alimentary tract. Brit. J. Nutr. 15:531-544.

Church, D.C. 1979. Digestive physiology and nutrition of ruminants. Vol. II. 0 \& B Books Inc., Corvallis, Ore.

Cordova, F.J., J.D. Wallace, and R.D. Pieper. 1978. Forage intake by grazing livestock: a review. J. Range Manage. 31:340-348.

Dubose, L.E., and L.B. Embry. 1956. Daily variation in dry matter excretion by steers and lambs. Proc. South Dakota Acad. Sci. 35:101-111.

Ellis, W.C. 1978. Determinants of grazed forage intake and digestibility. J. Dairy Sci. 61:1828-1840.

Goering, H.K., and P.J. Van Soest. 1970. Forage fiber analysis. USDA, ARS, Agr. Handbook 379.

Harris, L.E. 1970. Nutrition research technique for domestic and wild animals, Vol. I, L.E. Harris, Utah State Univ., Logan. p. 5501-5507.

Hendricksen, R.E., D.P. Poppi, and D.J. Minson. 1981. The voluntary intake, digestibility and retention time by cattle and sheep of stem and leaf fractions of a tropical legume (Lalab purpureus). Aust. J. Agr. Res. 32:389-398.
Ingalls, J.R., J.W. Thomas, M.G. Tesar, and D.L. Carpenter, 1966. Relations between ad libitum intake of several forages and gut fill. J. Anim. Sci. 25:283-289.

Kartchner, R.J., and C.M. Campbell. 1980. Intake and digestibility of range forages consumed by livestock. Montana Agr. Exp. Sta. and USA, EAR-AR Bull. 718.

McLeod, M.N., and D.J. Minson. 1974. Predicting organic-matter digestibility from in vivo and in vitro determinations of dry-matter digestibility. J. Brit. Grassl. Soc. 39:17-26.

Mertens, D.R. 1973. Application of theoretical and mathematical models to cell wall digestion and forage intake of ruminants. Ph.D. Thesis, Cornell Univ., Ithaca, N.Y.

Mertens, D.R. 1977. Dietary fiber components: relationship to the rate and extent of ruminal digestion. Federation Proc. 36:187-192.

Mertens, D.R., and L.O. Ely. 1982. Relationship of rate and extent of digestion to forage utilization - a dynamic model evaluation J. Anim. Sci. 54:895-905.

Milchunas, D.G., M.I. Dyer, O.C. Wallmo, and D.E. Johnson. 1978. In vivo- in vitro relationships of Colorado mule deer forages. Colorado Div. Wildlife Spec. Rep. 43. Fort Collins.

Moore, J.E. 1970. Procedures for the two-stage in vitro digestion of forages. In: p. 5501. Nutrition Research Techniques for Domestic and Wild Animals, Vol. 1. L.E. Harris, Utah State Univ., Logan.

Poppi, D.P., D.J. Minson, and J.H. Ternouth. 1980. Studies of cattle and sheep eating leaf and stem fractions of grasses. I. The voluntary intake digestibility, and retention time in the reticulo-rumen. Aust. J. Agr. Res. 32:99-108

Scales, G.H., C.L. Streeter, A.H. Denham, and G.M. Ward. 1974. A comparison of direct methods of predicting in vitro digestibility of grazed forage. J. Anim. Sci. 38:192-199.

Schneider, B.H., and W.P. Flatt. 1975. The Evaluation of Feeds through Digestibility Experiments. Univ. of Georgia Press, Athens.

Sidahmed, A.E., J.G. Morris, L.J. Koong, and S.R. Radosevich. 1981. Contribution of mixtures of three chaparral shrubs to the protein and energy requirements of Spanish goats. J. Anim. Sci. 53:1391.

Steel, R.G.D., and J.H. Torrie. 1960. Principles and procedures of statistics. McGraw-Hill Book Co., Inc., New York.

Tilley, J.M.A., and R.A. Terry. 1963. A two-stage technique for in vitro digestion of forage crops. J. Brit. Grassl. Soc. 18:104-111.

Urness, P.J., A.D. Smith, and R.K. Watkins. 1977. Comparison of in vivo and in vitro dry matter digestibility of mule deer forages. J. Range Manage. 30:119-121.

Van Dyne, G.M. 1969. Measuring quantity and quality of the diet of large herbivores. In:F.G. Folley and H.K. Beuchner, eds. A Practical Guide to the Study of the Productivity of Large Herbivores. Blackwell Scientific Publ., Oxford, England.

Van Dyne, G.M., and J.H. Meyer. 1964. A method for measuring forage intake by livestock using microdigestion techniques. J. Range Manage. 17:204-208.

Van Soest, P.J. 1982. Nutritional ecology of the ruminant. O \& B Books, Inc., Corvallis, Ore.

Wilkins, R.J., and R.C. Grimes. 1966. Herbage digestibility in sheep and corresponding estimates of digestibility in vitro. Proc. Aust. Soc. Anim. Prod. 6:334-339. 